\title{
Probabilistic design of mechanically-jointed timber beams using Eurocode 5
}

\author{
Salisu Dahiru ${ }^{1}$, Abubakar Idris ${ }^{1}$, Ejeh Stephen Phinder ${ }^{1}$ and Afolayan Joseph Olasehinde ${ }^{2}$ \\ ${ }^{1}$ Dept. of Civil Engg, Ahmadu Bello University, Zaria; ${ }^{2}$ Dept. of Civil Engg, Federal University of Tech., Akure, Nigeria \\ idrcivil1@yahoo.com
}

Abstract: A computer program that automates a probability-based design of mechanically-jointed timber Ibeams subjected to gravity loading is presented. The specifications of the EC-5 (1995) and EN 338 timber strength classes were strictly followed in the program development. In addition, first order reliability method (FORM) was adopted in checking the safety of the designed section. Failure of bottom flange due to extreme fibre tensile stress produced the most uneconomical results. The maximum shear stress condition on the other hand, gave the most critical results of design. Therefore it is considered to be the most critical mode failure for mechanically jointed timber I-beams subjected to gravity loads.

Keywords: Probabilistic design, mechanically jointed timber beams, I-section, EC-5

Introduction

The Eurocode 5 (EC-5) which is a limit state design code (Blass et al., 1995) utilizes partial safety co-efficient method in which the strength values are reduced through partial safety factors and the load actions multiplied by further factors of safety. This is with the aim of achieving low probability of failure of structures being designed for.

Engineering design decisions are surrounded by uncertainties that result from the random nature of loading and structural resistance as well as the load and resistance prediction models. The effect of such uncertainties is included in design through the use of safety factors that are based on engineering judgment and previous experience with similar structure. Due to the fact that safety involves a consideration of random variables and the realization of the limitations in design by the deterministic method, it is now generally accepted that the rational approach to the analysis of safety is through the use of probabilistic models (Ellingwood, 1979; Verderaime, 1994; Thoft-Christensen, 2002).

The study of structural safety is concerned with the calculation and prediction of the probability of limit state violation for engineered structures at any stage during their life. In particular, the study of structural safety is concerned with the violation of the ultimate or safety limit states for the structure (Madsen et al., 1999; Melchers, 1999).

The EC-5 has been found to be conservative (Afolayan, 2001; Salisu, 2007). Hence it is necessary to devote particular attention to the evaluation of the level of safety implied in the design criteria of mechanicallyjointed timber beams designed with EC-5.

In this paper, design requirements of EC-5 for mechanically-jointed timber beams are used with probability concept to derive design values for crosssectional dimensions at predefined safety levels. Design was said to be satisfactory when all the variables were considered stochastic with practical probability density functions and varying coefficient of variations. In the design process the first order reliability method (FORM) was adopted to calculate the structural safety of the beam considering the variability in the design variables using FORTRAN-based design program. FORTRAN programming language was adopted in order to access FORM (Gollwitzer et al., 1988).

First order reliability procedure

In the evaluation of safety using probabilistic concepts it is often the practice to define a safety margin $Z$ on the basis of the performance function $g\left(x_{1}, \ldots, x_{n}\right)$ which relates the resistance of the component to the applied loading. That is, $\quad Z=g\left(x_{1}, \ldots, x_{n}\right)$

Since the individual members of this function may be random quantities $Z$ also must be a random variable which must satisfy the condition that $Z>0$ at the internal points of the safe set, $Z=0$ at the limit state, and $Z<0$ at the internal points of the failure set. A generalized simple safety index can be formed if the random variables collected in the vector $X$ are normalized and collected in another vector $Y$ using a linear mapping of the kind $X=$ $L(Y)$ such that $Y=L^{-1}(X)$. Therefore the corresponding space of points is then defined by the transformation
$\mathrm{x}=\mathrm{L}(\mathrm{y})$,
$y=L^{-1}(x)$

The consequence of this transformation maps equation (1) at the limit state into

$\mathrm{h}\left(\mathrm{y}_{1}, \ldots, \mathrm{y}_{\mathrm{n}}\right)=0$

in which

$h(y)=g(L(y))$

The mean value of $Y$ occurs at the origin while the projection of $Y$ on a straight line through the origin is a random variable with a unit standard deviation. The distance from the origin to the limit state surface in this normalized space becomes the geometric safety index. In other word,

$$
\beta=\min \left\{\sqrt{\mathbf{y}^{\prime} \mathbf{y}} \mid h(\mathbf{y})=0\right\}
$$

where the minimum of the distance $\beta$ from the origin to $y$ is obtained for varying y over the entire limit state surface. A point $y$ on this limit surface that actually corresponds properly to the globally most central limit-state point is the checkpoint corresponding to probable failure point.

\section{Structural design considerations}

\section{Structural configuration}

In this study, the structural configuration of the mechanically-joined timber I-beam was developed based on the following assumptions:

i) The beam is part of a floor system for a timber frame have spanning $6 \mathrm{~m}$ and spaced $500 \mathrm{~mm} \mathrm{c/c}$

ii) imposed load on floor is $2.0 \mathrm{kN} / \mathrm{m}^{2}$
Research article

CIndian Society for Education and Environment (iSee)

\section{"Probabilistic design" \\ http://www.indjst.org}

Salisu Dahiru et al. Indian J.Sci.Technol. 
iii) solid timber ((joists) shall be used for flanges while plywood will be used for the web.

iv) building is a dwelling from service class one

Timber strength classes for timber components

The following are the timber strength class $\mathrm{C} 14$ properties for the various components of the mechanically-joined timber l-beam (Fig.1).

Flanges: strength class is $\mathrm{C} 14$ in accordance with to EN338 (Blass et al., 1995), has the following characteristics:

Bending stress, $f_{m, k}=14 \mathrm{~N} / \mathrm{mm}^{2}$

Elastic modulus of flange, $E_{f}=7000 \mathrm{~N} / \mathrm{mm}^{2}$

Characteristic tensile strength parallel to grain,

$\mathrm{f}_{\mathrm{t}, 0, \mathrm{~g}, \mathrm{k}}=8 \mathrm{~N} / \mathrm{mm}^{2}$

Characteristic compressive strength parallel to grain,

$\mathrm{f}_{\mathrm{c}, 0, \mathrm{~g}, \mathrm{k}}=16.00 \mathrm{~N} / \mathrm{mm}^{2}$

Modification factor, $\mathrm{k}_{\mathrm{c}}=0,95$

Deformation modification factor

$\mathrm{K}_{\text {def }}=0.60$

$W e b$ : is made up of plywood in accordance with the provisions of EN312, part 6.

Thickness of web, $t=24 \mathrm{~mm}$

Elastic modulus of web $E_{w}=2475 \mathrm{~N} / \mathrm{mm}^{2}$
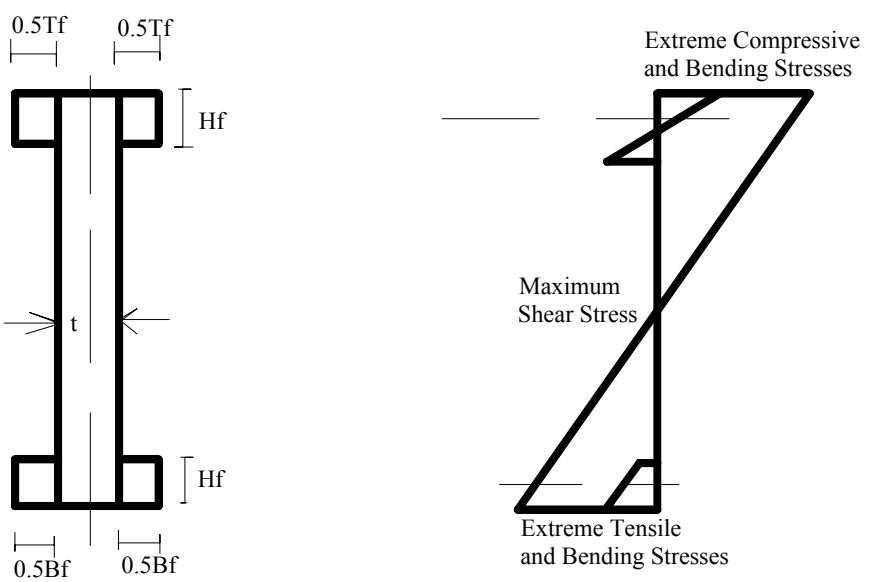

Fig. 1. Structural configuration of mechanically-jointed timber I-beam

Models of mechanically jointed timber I-beam to EC - 5

The calculation of the mechanical models is performed for discrete combination of basic variables considering failure modes outlined in the EC - 5 design provisions. These are given as follows:

Failure mode I: bending of top and bottom flanges

The flange bending strength (EC - 5) is given by:

$F_{t, 0, g, d}=\frac{\left(k_{\text {mode }} f_{t, 0, g, k}\right)}{f_{m}}$

The mechanical model considering bending of top and bottom flanges is therefore:

$\mathrm{GX}=\left[\mathrm{f}_{\mathrm{m}, 0, \mathrm{~g}, \mathrm{~d}}-\sigma_{\mathrm{m}, 1, \mathrm{~d}}\right]$

Failure mode II: maximum shear stress in the web

The maximum shear stresses occur where the normal stresses are zero. The maximum shear stresses in the web member should be taken as (EC - 5,1995$)$ $\tau_{2, \text { maqx }}=\frac{\mathrm{y}_{3} \mathrm{~A}_{3} \mathrm{E}_{3} \mathrm{a}_{3}+0.5 \mathrm{E}_{2} \mathrm{~b}_{2} \mathrm{~h}_{2}}{\mathrm{~b}_{2}(\mathrm{EI})_{\text {eff }}}$

The design shear strength in the web is given as:

$F_{\mathrm{v}, 0, \mathrm{~g}, \mathrm{~d}}=\frac{\boldsymbol{k}_{\mathrm{mod}}\left(\mathrm{f}_{\mathrm{v}, 0, \mathrm{~g}, \mathrm{~d}}\right)}{\mathrm{Y}_{\mathrm{m}}}$

Therefore, the mechanical model considering shear stress in the web is:

$\mathrm{G}(\mathrm{X})=\left[\mathrm{f}_{\mathrm{v}, 0, \mathrm{~g}, \mathrm{~d}}-\tau_{2, \max }\right]$

Failure Mode III: Compressive stress in top flange

Design compressive stress in top flange considering the $\mathrm{EC}$ - 5 considerations is given by

$F_{c, i, d}=\frac{k_{\text {mod }}\left(f_{c, i, k}\right)}{Y_{m}}$

and, the corresponding mechanical model is by given by

$\mathrm{G}(\mathrm{X})=\left[\mathrm{f}_{\mathrm{c}, \mathrm{i}, \mathrm{d}}-\sigma_{\mathrm{m}, 1}\right]$

Failure mode IV: Tensile stress in the bottom flange

The EC - 5 gives the design tensile strength in the bottom flange as

$F_{t, w, g, d}=\frac{k_{\text {mod }}\left(f_{t, i, k}\right)}{f_{m}}$

The mechanical model is therefore:

$\mathrm{G}(\mathrm{X})=\left[\mathrm{f}_{\mathrm{t}, \mathrm{i}, \mathrm{d}}-\sigma_{\mathrm{m}, 3}\right]$

As proposed in this study, a design is considered satisfactory if the following condition is satisfied:

\section{$\beta \approx \beta_{T}$}

Where $\beta$ is the calculated safety index obtained from the reliability program on the basis of the input variables (Gollwitzer et al., 1988) and $\beta_{\mathrm{T}}$ is the target safety index (Afolayan \& Abubakar, 2003). If the above condition does not hold, the design of the individual footing is repeated until it is satisfied. When the condition is satisfied for varying values of the design variables, the parameters so obtained are considered to provide uniform reliability.

Probabilistic design procedure

Because of compatibility to FORM (Gollwitzer et al., 1988), A FORTRAN based program was developed for each of the four modes of failure listed in section 3 in order to automate the probabilistic design of the beam. The flowchart of the program is as shown in Fig. 2. The program is flexible and capable of accepting design information. The program user has to enter the design variables such as density of timber, member dimensions, fastener spacing, and the ratio of dead-to-live loads, as well as the target safety index. The design of the I-section will first be carried in accordance with EC-5 design requirements. The design output will then be the input stochastic variables of the FORM, in order to obtain the safety of the designed section. A design is said to be satisfactory if the condition set out in equation (15) is satisfactory, else the procedure is to be repeated for varying values of the design variables, until it is satisfactory.

\section{Results of probabilistic design}

A simply supported beam of configuration and properties listed in section 3 was designed at various
Research article

CIndian Society for Education and Environment (iSee)
"Probabilistic design"

http://www.indjst.org
Salisu Dahiru et al. Indian J.Sci.Technol. 
target safety indices. In each case, design was carried out in accordance with the modes of failure given by EC-5 given in the previous section. Design was considered satisfactory if the implied safety index is in accordance with NKB (1978) guide.

As a demonstration of this design concept, design parameters such as the depth of top and bottom flanges, width of top, and bottom flanges, width of web, coefficient of variation of member strengths, member elastic modulus and density, member length, target safety index and other relevant variables were kept constant in the program.

However, the ratio of dead-to-live load is the only variable that is required in the main program for the specified

Table 1: Design depth of web (load

\begin{tabular}{|c|c|c|c|}
\hline Failure & \multicolumn{2}{|c}{ ratio $\alpha=0.2$ ) } \\
modes & $\begin{array}{c}\text { Target } \\
\text { safety } \\
\text { index }\end{array}$ & $\begin{array}{c}\text { Coefficient of } \\
\text { variation } \\
\text { of member } \\
\text { strength }\end{array}$ \\
\cline { 2 - 4 } & & $10 \%$ & $20 \%$ \\
\hline Failure & 2.0 & 325 & 355 \\
\cline { 2 - 4 } mode & 2.5 & 335 & 380 \\
\cline { 2 - 4 } & 3.0 & 345 & 415 \\
\cline { 2 - 4 } & 3.5 & 360 & 460 \\
\hline Failure & 2.0 & 250 & 250 \\
\cline { 2 - 4 } mode & 2.5 & 250 & 250 \\
\cline { 2 - 4 } II & 3.0 & 250 & 280 \\
\cline { 2 - 4 } & 3.5 & 250 & 360 \\
\hline Failure & 2.0 & 355 & 385 \\
\cline { 2 - 4 } mode & 2.5 & 365 & 415 \\
\cline { 2 - 4 } III & 3.0 & 380 & 450 \\
\cline { 2 - 4 } & 3.5 & 390 & 500 \\
\hline Failure & 2.0 & 410 & 460 \\
\cline { 2 - 4 } mode & 2.5 & 420 & 485 \\
\cline { 2 - 4 } IV & 3.0 & 435 & 515 \\
\cline { 2 - 4 } & 3.5 & 550 & 550 \\
\hline
\end{tabular}

failure mode. In that case the design parameter of interest in the safety check is the depth of web for all failure modes. This approach was adopted in a study on glued thin webbed beam performed by (Afolayan, 2005). The value of components' cross sectional dimensions apart from depth of web is considered as part of the input variables in the program. Then determination of depth of web that satisfies the target safety index, coefficient of variation of member strength and ratio of dead to live load are automated. The results obtained are as presented in Tables 1 to 3 . From the results presented in the tables above, as the target safety index was increased, required web thickness increased. That is, lower safety indices produce more

Research article

CIndian Society for Education and Environment (iSee)
"Probabilistic design" http://www.indjst.org
Vol.2 No. 10 (Oct 2009)

ISSN: 0974- 6846

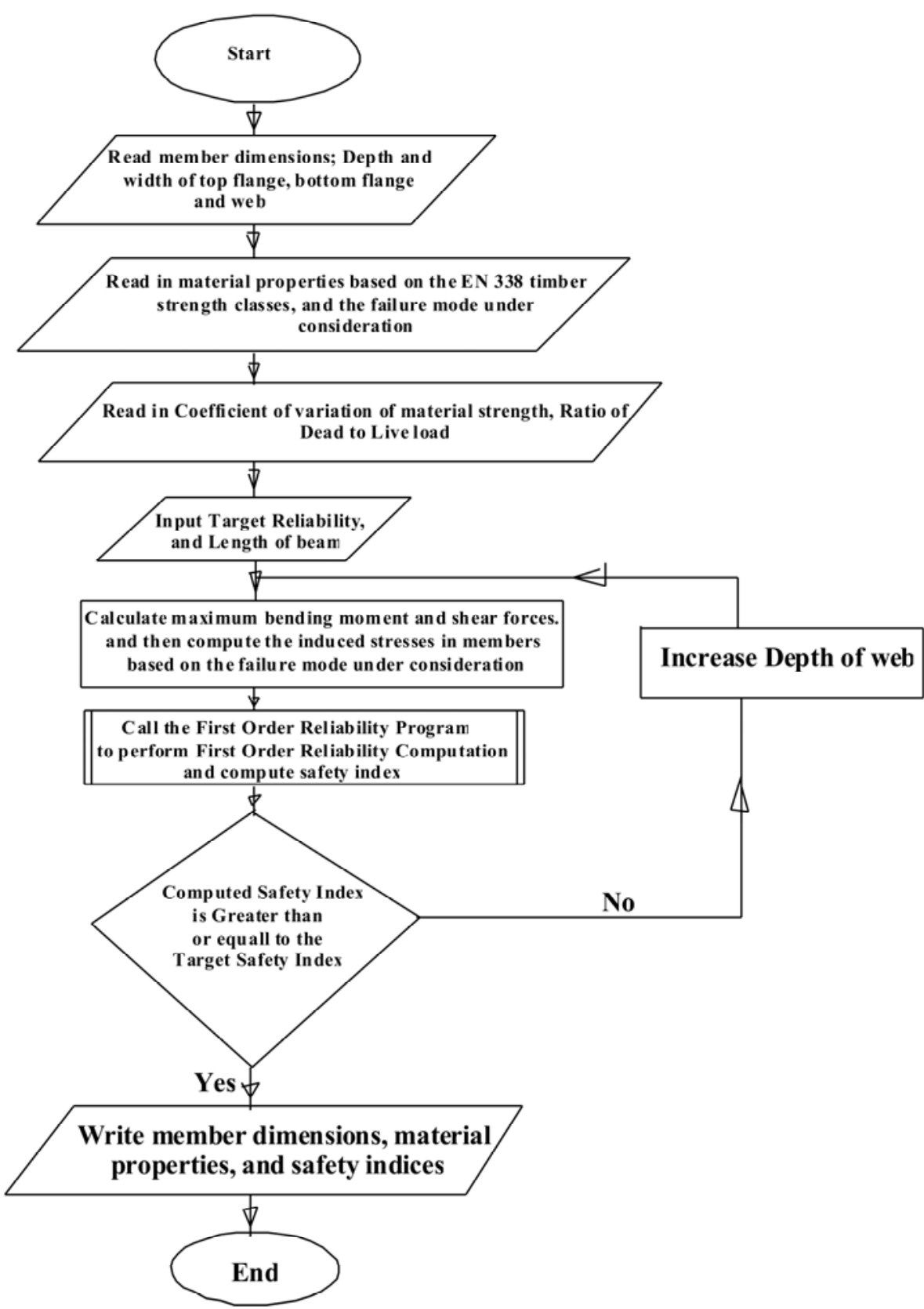

Fig. 2. Flowchart of probabilistic design program

economical thicknesses of web. Also, as the magnitude of dead-to-live load ratio was increased, web thickness increased correspondingly. Again, as the coefficient of variation was increased, the resulting thickness of web increased.

The results obtained showed that failure of bottom flange due to extreme fibre tensile stress produced the most uneconomical results.

Finally, it can be seen that lower web depths were produced when failure mode II (maximum shear stress in the web) was considered. Design results from mode II 
therefore produce the least thickness of web, which is therefore the most critical design mode. This is because

design results from failure mode II cannot satisfy the design requirements of the other three modes of failure.

\section{Conclusion}

A computer program in FORTRAN 77 programming language has been developed to automate the probability-based design of mechanically-jointed timber I-section beams subjected to gravity loading only. The specifications of the EC-5 (1995) and EN 338 timber

strength classes (Blass et al., 1995) were strictly followed in the program development. In
Table 2. Design depth of web (load ratio, $\alpha=0.5$ )

\begin{tabular}{|c|c|c|c|}
\hline Failure & $\begin{array}{c}\text { Target } \\
\text { safety } \\
\text { index }\end{array}$ & \multicolumn{2}{|c|}{$\begin{array}{c}\text { Coefficient of variation } \\
\text { of member strength }\end{array}$} \\
\cline { 2 - 4 } & & $10 \%$ & $20 \%$ \\
\hline Failure & 2.0 & 350 & 385 \\
\cline { 2 - 4 } mode & 2.5 & 365 & 410 \\
\cline { 2 - 4 } & 3.0 & 375 & 450 \\
\cline { 2 - 4 } & 3.5 & 390 & 500 \\
\hline Failure & 2.0 & 250 & 250 \\
\cline { 2 - 4 } mode & 2.5 & 250 & 275 \\
\cline { 2 - 4 } II & 3.0 & 250 & 335 \\
\cline { 2 - 4 } & 3.5 & 250 & 420 \\
\hline Failure & 2.0 & 385 & 420 \\
\cline { 2 - 4 } mode & 2.5 & 395 & 450 \\
\cline { 2 - 4 } III & 3.0 & 410 & 490 \\
\cline { 2 - 4 } & 3.5 & 425 & 545 \\
\hline Failure & 2.0 & 460 & 520 \\
\cline { 2 - 4 } mode & 2.5 & 470 & 550 \\
\cline { 2 - 4 } IV & 3.0 & 485 & 585 \\
\cline { 2 - 4 } & 3.5 & 500 & 630 \\
\hline
\end{tabular}

8. Gollwitzer $\mathrm{S}$, Abdou $\mathrm{T}$ and Rackwitz RO (1988) First order reliability method user guides, Munich, Germany.

9. Madsen, $\mathrm{HO}$, Addo $\mathrm{T}$ and Lind NC (1999) Methods of structural safety, Prentice Hall.

10. Melchers RE (1999) Structural reliability analysis and prediction. John Wiley \& Sons, New York.

11. NKB

Recommendation for loading and safety regulations for structural design. Nordic Committee on Building Regulation. Report No: 36, Press Ltd., London, UK.

12. Salisu D (2007) Probabilistic design of mechanically jointed timber beams under addition, FORM was used in checking the safety of the designed section. This is an aspect, which the current code of practice did not address.

It was further shown from the results that failure of bottom flange due to extreme fibre tensile stress produced the most uneconomical results. The maximum shear stress condition gave the most critical results of design; and can therefore be said that it is the most critical mode failure for mechanically jointed timber Ibeams subjected to gravity loads.

\section{References}

1. Afolayan JO (2001) Reliability model for wooden floors: initial design. Asian J. Civil Engg. 2, 225-232.

2. Afolayan JO (2005) Probability-based design of glued thin-webbed timber beams. Asian J. Civil Engg. 6, (1), 75-84.

3. Afolayan JO and Abubakar I (2003) Reliability-based design program for reinforced concrete one-way slabs to BS8110 (1985). Nig. J. Engg. 11, 1-6.

4. Blass HJ, Aune P, Choo BS, Goerlacher R, Griffths DR and Hilson BO (1995) Timber Engg step $11^{\text {st }}$ Ed. Centrum Hout, the Netherlands.

5. Conference on Bridge Maintenance, Safety and Management, IABMAS, http://www.civil.auc.dk/i6.

6. Ellingwood B, Galambos TV, MacGregor JG and Cornell CA (1980) Development of probability-based load criterion for American national standard A58. Special publication 577, National Bureau of Standards, Washington, pp: 222.

7. Eurocode 5 (1995) Design of timber structures part 1.1. General rules and rules for buildings. Publ. of European Committee for Standardization.
Table 3. Design depth of web (load ratio, $a=1.0$ )

\begin{tabular}{|c|c|c|c|}
\hline \multirow{2}{*}{$\begin{array}{c}\text { Failure } \\
\text { modes }\end{array}$} & $\begin{array}{c}\text { Target } \\
\text { safety } \\
\text { index }\end{array}$ & \multicolumn{2}{|c|}{$\begin{array}{c}\text { Coefficient of variation } \\
\text { of member strength }\end{array}$} \\
\cline { 2 - 4 } & & $10 \%$ & $20 \%$ \\
\hline \multirow{3}{*}{$\begin{array}{c}\text { Failure } \\
\text { mode }\end{array}$} & 2.0 & 390 & 425 \\
\cline { 2 - 4 } & 2.5 & 405 & 455 \\
\cline { 2 - 4 } & 3.0 & 415 & 495 \\
\cline { 2 - 4 } & 3.5 & 430 & 550 \\
\hline \multirow{3}{*}{$\begin{array}{c}\text { Failure } \\
\text { mode }\end{array}$} & 2.0 & 250 & 300 \\
\cline { 2 - 4 } II & 2.5 & 260 & 350 \\
\cline { 2 - 4 } & 3.0 & 285 & 420 \\
\cline { 2 - 4 } Failure & 3.5 & 310 & 515 \\
\cline { 2 - 4 } mode & 2.0 & 425 & 465 \\
\cline { 2 - 4 } & 2.5 & 450 & 495 \\
\cline { 2 - 4 } & 3.0 & 455 & 540 \\
\hline \multirow{2}{*}{$\begin{array}{c}\text { Failure } \\
\text { mode }\end{array}$} & 3.5 & 470 & 605 \\
\cline { 2 - 4 } IV & 2.0 & 540 & 615 \\
\cline { 2 - 4 } & 2.5 & 555 & 660 \\
\cline { 2 - 4 } & 3.0 & 575 & 705 \\
\hline
\end{tabular}

gravity loads. Unpublished M.Sc. Thesis, Dept. of Civil Eng., Ahmadu Bello Univ., Zaria, Nigeria.

13. Thoft-Christensen $P$ (2002) Deterioration of concrete structures, I ${ }^{\text {st }}$ International.

14. Verderaime V (1994) Illustrated structural application of universal first-order reliability method. NASA Tech. Paper 3501, Natl. Aeronautics \& Space Admin. http://trs.nis.nasa.gov/archive/00000253/01/tp3501.p df
Research article

CIndian Society for Education and Environment (iSee)
"Probabilistic design" http://www.indjst.org 